\title{
The Role of Baitul Maal Wa Tamwil in the Economic Empowerment of Poor Women in Cianjur District
}

\author{
Uus Ahmad Husaeni ${ }^{\left.1^{*}\right)}$, Selviana Zakiah ${ }^{2)}$ \\ ${ }^{1}$ Fakultas Ekonomi dan Bisnis Islam, Universitas Suryakancana \\ ${ }^{2}$ Program Magister Ekonomi Islam, UIN Sunan Gunung Djati Bandung \\ * Email correspondence: uusahmadhusaeni@unsur.ac.id
}

\begin{abstract}
This study aims to analyze BMT's role in poor women's economic empowerment in the Cianjur Regency. This research is a qualitative descriptive study using economic and sociological approaches. This research's data sources are primary data obtained from BMT and interviews and secondary data from library research. Furthermore, the data collection method is carried out by observation, interviews, and documentation for further analysis by reducing data, presenting data, and drawing conclusions. The results showed that BMT played a role in empowering the economy of women. Their income increases so that they can meet their daily needs and become more independent. Besides, they became smarter in managing finances and began to be actively involved in household decision making. Empowerment of women can improve women's welfare and independence in various aspects of life, particularly the economy. Applying the function of empowering women in microfinance institutions such as BMT is the right solution to improve the economy of the community, especially women.
\end{abstract}

Keywords: BMT; Empowerment; Poor Women; Welfare.

Citation suggestions: Husaeni, U. A., \& Zakiah, S. (2021). The Role of Baitul Maal Wa Tamwil in the Economic Empowerment of Poor Women in Cianjur District. Jurnal Ilmiah Ekonomi Islam, 7(02), 917-923. doi:http://dx.doi.org/10.29040/jiei.v7i2.2129

DOI: http://dx.doi.org/10.29040/jiei.v7i2.2129

\section{INTRODUCTION}

Islamic economics views that poverty is synonymous with suffering, misery, injustice, and asset distribution, only for some unproductive groups (Husaeni and Dewi, 2019). This is, of course, contrary to the goal of Islamic economics, namely to achieve Falah (happiness), of course by paying attention to the benefit of the people, for that, the role of Sharia Banks and Islamic People's Financing Banks as Islamic financial institutions must be able to achieve the goals of the Islamic economy itself (Sobana and Husaeni, 2019). However, these two types of Islamic financial institutions have not been able to reach the lower layers of Islamic society. Therefore, savings and loan institutions were formed called Baitul Maal Wattamwil (BMT).

BMT is a sharia microeconomic institution engaged in collecting and distributing financing to small communities, whether it is social (non-profit) such as Zakat, donations, alms or distribution, and business capital funding is profit with a profit-sharing system (Ridwan, 2011). BMT's presence can be an alternative solution for the Indonesian economy, where most of the people are engaged in Micro, Small, and Medium Enterprises. This is because BMT is more flexible and can reach middle to lower class people. This is proven by the establishment of Grameen Bank in Bangladesh, and in Indonesia, the Gakin Bank, a bank for needy families, has been established. Grameen Bank and Bank Gakin focus loans to poor women. The credit that these two financial institutions have given has brought new enthusiasm for women. Family income increases and they become more independent (Amalia, 2009).

Economic empowerment for poor women is essential, given women's position as deputy heads of 


\section{Jurnal Ilmiah Ekonomi Islam, 7(02), 2021, 918}

households who can support household income fulfilment other than husbands, especially for underprivileged families (Husaeni and Dew, 2019; Shastri, 2009). Poor women's dual role makes it even more complicated in carrying out the tasks they are assigned. However, women have more creative ideas to generate additional money to help their husbands with their various creativities (Sen, 1981). Therefore, the potential for women from the middle to lower classes can be the focus of Islamic financial institutions, especially BMT, to help women's capital to be able to develop (Chowdhury, 2009). Based on the above facts, the researcher observes the need for research on this matter to map well whether the financing provided by BMT has contributed to empowering poor women or not, especially in the Cianjur Regency, one of the districts with the highest poverty rate in West Java.

\section{METHOD}

This research is qualitative, qualitative is a research method that aims to gain an understanding of reality through an inductive thought process. Through qualitative research, researchers can identify subjects and feel what they experience in everyday life (Basrowi and Suwandi, 2008). In comparison, this type of research is field research, which aims to study and understand intensively about the background of the current situation and environmental interactions according to social units, individuals, groups, institutions, or communities. The data sources of this research were taken from primary and secondary data. Primary data is data that is directly obtained from the first data source at the research location.

Meanwhile, secondary data is data obtained from a second source or secondary source of the information we need (Bungin, 2005). Thus, this study's primary data source is the data obtained from BMT and BMT members as the interview source. While secondary data is obtained from library research, namely by collecting, reading, and understanding books, articles, books, journals, magazines, or data from the internet related to this research.

\section{RESULTS AND DISCUSSIONS}

\subsection{BMT Products and Services}

BMT products come in two forms. First, raising funds (Funding) through savings that uses them with principle. The second is channelling funds (Lending) through financing consisting of profit sharing and buying and selling. Savings or savings can be interpreted as a pure deposit from an individual or business entity to the BMT. Types of savings or savings are as follows: Mandiri Sejahtera Savings (TAMARA), regular savings that can be taken at any time, Children's Education Savings (TADIKA), Savings specifically for children's education preparation. Idul Fitri Savings (TADURI), a saving that is devoted to preparing for Eid. Withdrawals are made once before Eid. Aqiqah Savings (TAQIQ) Savings dedicated to the preparation of Aqiqah, Qurban Savings, Savings specifically for Qurbani / Eid al-Adha's practice Time Savings (TAJAKA), Savings that have a shelf life of 3, 6, 12 months. This deposit is a savings or investment using the mudharabah mutlaqah principle, which can be withdrawn according to a specified period. Bungkesmas is a savings account plus health and accident insurance specially designed for cooperatives, BMT, LKM, and similar financial institutions. In this case, BMT collaborates with Bungkesmas providers to be offered to members (Ridwan, 2011).

The financing consists of profit sharing and buying and selling, among others: Profit sharing is carried out between BMT and fund managers and providers of funds (depositors/savers). This profit sharing is divided into 1) Musharaka is a partnership between two or more parties in a project where each party is entitled to all profits and is responsible for all losses incurred following their respective participation (Jayengsari and Husnaeni, 2020); 2) Mudharabah is a partnership between two parties in which the first party (shahib al Amal) provides funds and the second party (mudharib) is responsible for business management. Profits are distributed according to the profit ratio agreed upon in advance. When the loss, shahib al Amal / will lose part of the rewards of hard work and managerial skills during the project; 3) Muzaraah is financing carried out by BMT by giving 


\section{Jurnal Ilmiah Ekonomi Islam, 7(02), 2021, 919}

one land to the cultivator to be planted and maintained in exchange for a particular share (percentage) of the harvest; 4) Musaqot is a more straightforward form of muzaraah where BMT assigns responsibility to the cultivator for watering and maintenance. In return, the cultivator is entitled to a specific ratio of the harvest.

Sale and Purchase (Profit) is a buying and selling procedure in which, in its implementation, BMT appoints the customer as an agent (who is given the power) to purchase goods on behalf of BMT. BMT acts as a seller to the customer at a purchase price plus profit for BMT or margin. The benefits that BMT gets will be shared with providers and depositors of funds. The types are: 1) Murabahah is a sale and purchase agreement between a financing member and BMT, which states the purchase price (purchase price) plus the profit or margin agreed by both parties. BMT buys the items needed by members on behalf of BMT. Then the goods are given to the financing member at the introductory price plus a known and mutually agreed on profit and instalments within a certain period; 2) Bai Bitsaman Ajil (BBA) is a process of buying and selling between BMT and members, where payment is made simultaneously with the delivery of goods; 3 ) Bai As-Salam, the process of buying and selling between financing members and BMT where payment is made first, and delivery of goods is carried out later; 4) $\mathrm{Al}$ Istishna is an order contract signed simultaneously between the customer and the producer for the manufacture of certain types of goods and the payment can be paid in instalments at a later date; 5) Bai Ut Takjiri is a lease contract between BMT which ends with a sale. In this contract, the lease payments have been calculated in such a way that it constitutes a gradual purchase of the goods.

\subsection{Financing Procedure at BMT}

BMT products come in two forms. First, raising funds (Funding) through savings that uses them with principle. The second is channelling funds (Lending) through financing consisting of profit sharing and buying and selling. Savings or savings can be interpreted as a pure deposit from an individual or business entity to the BMT. Types of savings or savings are as follows: Mandiri Sejahtera Savings (TAMARA), regular savings that can be taken at any time, Children's Education Savings (TADIKA),
Savings specifically for children's education preparation. Idul Fitri Savings (TADURI), a saving that is devoted to preparing for Eid. Withdrawals are made once before Eid. Aqiqah Savings (TAQIQ) Savings dedicated to the preparation of Aqiqah, Qurban Savings, Savings specifically for Qurbani / Eid al-Adha's practice Time Savings (TAJAKA), Savings that have a shelf life of 3, 6, 12 months. This deposit is a savings or investment using the mudharabah mutlaqah principle, which can be withdrawn according to a specified period. Bungkesmas is a savings account plus health and accident insurance specially designed for cooperatives, BMT, LKM, and similar financial institutions. In this case, BMT collaborates with Bungkesmas providers to be offered to members (Ridwan, 2011).

The financing consists of profit sharing and buying and selling, among others: Profit sharing is carried out between BMT and fund managers and providers of funds (depositors/savers). This profit sharing is divided into 1) Musharaka is a partnership between two or more parties in a project where each party is entitled to all profits and is responsible for all losses incurred following their respective participation (Jayengsari and Husnaeni, 2020); 2) Mudharabah is a partnership between two parties in which the first party (shahib al Amal) provides funds and the second party (mudharib) is responsible for business management. Profits are distributed according to the profit ratio agreed upon in advance. When the loss, shahib al Amal / will lose part of the rewards of hard work and managerial skills during the project; 3) Muzaraah is financing carried out by BMT by giving one land to the cultivator to be planted and maintained in exchange for a particular share (percentage) of the harvest; 4) Musaqot is a more straightforward form of muzaraah where BMT assigns responsibility to the cultivator for watering and maintenance. In return, the cultivator is entitled to a specific ratio of the harvest.

Sale and Purchase (Profit) is a buying and selling procedure in which, in its implementation, BMT appoints the customer as an agent (who is given the power) to purchase goods on behalf of BMT. BMT acts as a seller to the customer at a purchase price plus profit for BMT or margin. The benefits that BMT gets 


\section{Jurnal Ilmiah Ekonomi Islam, 7(02), 2021, 920}

will be shared with providers and depositors of funds. The types are: 1) Murabahah is a sale and purchase agreement between a financing member and BMT, which states the purchase price (purchase price) plus the profit or margin agreed by both parties. BMT buys the items needed by members on behalf of BMT. Then the goods are given to the financing member at the introductory price plus a known and mutually agreed on profit and instalments within a certain period; 2) Bai Bitsaman Ajil (BBA) is a process of buying and selling between BMT and members, where payment is made simultaneously with the delivery of goods; 3 ) Bai As-Salam, the process of buying and selling between financing members and BMT where payment is made first, and delivery of goods there are two types of financing from BMT, namely consumptive and productive financing. The two types of funding provided by BMT to its members are as follows: 1) Consumptive financing, namely financing required by users of funds to meet consumption needs and will be used up to fulfil these needs; 2) Working capital financing, namely investing to meet needs, increasing production, both quantitatively and qualitatively and for trading purposes or improving the utility of place of an item.

Before providing financing, the BMT will carry out a series of procedures. The first is to complete the financing application file at the BMT. The requirements for financing applicants are classified as easy; there is no difference between men and women. The requirements for applying for financing are: Have become a BMT partner, Fill out a financing application form, a copy of the husband/wife's ID card and a copy of a valid family card, a copy of the marriage book, a copy of the electricity bill for the last three months, a photograph of the husband/wife size $3 \times 4$ (2pcs). When conducting a field review to avoid bad credit, it is necessary to analyze the feasibility of financing as for some of the approaches used by BMT, namely: Character Approach, this approach is a data approach about the personality of prospective members of the financing such as 'traits, habits, ways of life, circumstances and his family background (personal guaranteed). This character is to find out whether the prospective member is honest and tries to fulfil his obligations. Feasibility Approach, business this approach looks at prospective members' ability to manage their business in terms of education, experience, and how to solve problems when running their business. This approach is used as a measure of the ability to pay. Collateral approach, namely the existence of guarantees that allow confiscation if it turns out that the prospective customer is genuinely unable to fulfil his obligations. Critical Point Approach, the financing provided also needs to consider the economic conditions associated with the prospect's business prospects. Business is highly dependent on economic conditions; therefore, it is necessary to link financial situations with the prospective customer's location is carried out later; 4) $\mathrm{Al}$ Istishna is an order contract signed simultaneously between the customer and the producer for the manufacture of certain types of goods, and the payment can be paid in instalments at a later date; 5) Bai Ut Takjiri is a lease contract between BMT which ends with a sale. In this contract, the lease payments have been calculated in such a way that it constitutes a gradual purchase of the goods.

\subsection{Economic Condition of Women Before and After Receiving Financing}

To know the changes in poor women's economic conditions before and after receiving financing from BMT, we must first see the use of the funding by these women members. From interviews conducted with female respondents who took funding, most of them used it as additional business capital, although a small proportion used it for children's education and house renovations. This shows that the level of women's desire to be independent is relatively high and not only entirely dependent on their husbands' income.

Respondents also admitted to using financing funds according to their objectives. When asked questions about economic conditions before and after receiving financing from BMT, each respondent had different answers. However, their solutions lead to the conclusion that by obtaining funding from BMT, the female members of this financing can meet their daily needs and become more independent. In general, financing funds are used to increase capital, stock of goods, and consumptive purposes.

Mrs. Hana (50 years) said that after receiving financing from BMT, she was more independent, 


\section{Jurnal Ilmiah Ekonomi Islam, 7(02), 2021, 921}

especially since her husband died, her daily needs became her responsibility. Since she was a BMT member and took financing, she was able to start a business by trading used clothes. Besides, Mrs. Yoyoh (52 years old), who sells rice every day, stated that since taking financing, her capital has continued to increase, even now she is not only rice of sale but also selling cakes that are kept in stalls around her house. "I have long been a customer of the Joint Business Group BMT, from the loans provided by BMT, I sell rice every morning, Alhamdulillah, now I am also able to sell cakes with the profits that are earned." The same thing was also expressed by Mrs. Yati (40 years), who owns a grocery store business, has taken several short-term financing to increase the stock of goods. But he admits that the funding from BMT has helped his business run smoothly. "Selling is not always busy, sometimes it is also quiet, so I took a loan to increase the stock of my merchandise. After all, he paid it every week, was a few days late, and BMT could still understand".

Other respondents expressed the same thing when asked about their families' economic condition after receiving financing from BMT. Almost all answered that the financial situation was better than before, and had even made significant progress, such as Mrs. Juju (38 years) who had just bought a motorbike because her business had progressed. However, some complained. After all, they felt burdened with monthly installments because their company was declining, but it was not said that the financing from BMT had no impact. This is experienced by Mrs. Fitri (30 years) as she said: "My husband doesn't have a permanent job, so I also have to help meet family needs. I received stitches from people. Recently, sewing orders are decreasing, so the family's income is barely enough. I was often late in paying installments, but $\mathrm{f}$, fortunately, the BMT people were still tolerant".

\subsection{Analysis of the Role of BMT in Economic Empowerment of Poor Women}

Women's participation is essential in empowerment-based development, achieving development goals (Durrani et al., 2011). Business development efforts facilitated by BMT through financing and fostering business groups are a necessity because women face certain constraints known as "triple burden of the woman". Three roles are carried by women, namely when they are asked to carry out reproductive, production, and social functions in the community at the same time, and this causes women's opportunities to take advantage of economic opportunities to be very limited (Yunus and Jolis, 2010).

Homemakers with weak economic conditions and low education levels also find it challenging to access limited access to capital services from large financial institutions such as banks and BPRS because they require complicated and burdensome administrative requirements. After describing the economic conditions of the respondents before and after receiving financing from BMT. The next researcher wants to analyze BMT's role in empowering the women's economy by using several benchmarks. The first is in terms of member initiative in taking financing. This desire can arise from yourself, husband, parents, and even neighbors. From the results of interviews that have been conducted with several respondents, the dominant answer is that they take the financing of their initiative - however, some responses their enterprise on the advice of their husbands.

This shows that women already have a high awareness of helping the family economy. Besides, initiatives have emerged from planning family finances and solving problems that arise in his family's economic life. With the high self-initiative of these members, it is hoped that women will be more independent and can be actively involved with their husbands in making decisions in the household.

Next is how the respondent's ability to manage finances after taking financing from BMT is the same as before or has increased. Because as we know that fundamental financial problems are often the main problem in everyday life, especially for those who are married. Therefore BMT will train and familiarize its members to manage finances properly, and this is an indirect role of BMT in women's economic empowerment. Some members said that their family's financial management was tidier than before because they had to be competent in setting aside money to pay their monthly installments. Others stated that there 


\section{Jurnal Ilmiah Ekonomi Islam, 7(02), 2021, 922}

was no difference with the previous one because previously they were used to recording income and expenses from their business. To analyze the role of BMT in empowering women's economy, the authors inquire more deeply about the respondent's ability to fulfill basic needs, personal needs, and children's needs. This is to determine the respondent's dependence on her husband. The following is the narrative of Mrs. Lia (31 years): "After I opened a shop at my own house when my child or I had a need, I didn't have to wait for a gift from my husband. I also often exchange ideas with my husband on various things. It is clear that based on one of the interview quotes above, the respondents have been able to help fulfill their daily needs and become more independent, so it can be concluded that they have been empowered. Apart from that, the respondents also dared to express their opinions in making decisions in the household.

\subsection{BMT's Efforts in Empowering Women's} Economy

From the previous discussion, it has been discussed that many women who take financing at BMT are indirectly empowered, then what about the BMT's efforts? Ms. Nurhayati, as the General Manager of a BMT in Cianjur Regency, stated that the particular program for women's empowerment is not impossible to achieve but is not easy either. Furthermore, he said that although he had not yet focused on empowering women, there were already thoughts and plans for the future. The following is his explanation: "Actually, there has been a plan for a long time, only we are constrained by capital because for this BMT business we are pursuing temporary income for the empowerment program there is a special fund that we do not target income. Moreover, in providing financing, we do not differentiate between men and women in determining whether they are eligible to receive financing. However, the financing members, both personal and those who join the BMT-assisted business group, are mostly women. Indeed, making a special program to empower women is not an easy job, but I think that women's empowerment has been included in it with our vision and mission. We also routinely carry out recitation as a means of gathering with BMT members".
Based on the analysis above, it is revealed that BMT has played a role in empowering the economy of women indirectly. Still, it needs follow-up from the BMT itself, namely striving for a particular program for women's economic empowerment so that the goal of improving the family economy for welfare can be realized. Empowering women is not a difficult thing if support from various parties arrives. Microfinance institutions such as BMT have an excellent opportunity to advance the economy of the middle to lower economic groups, especially women. However, BMT still faces obstacles in making it happen both in terms of the quality of BMT resources or socialization in the community. Also, talking about women's abilities, which are sometimes still underestimated in women's social stratification, is sometimes difficult to develop because they adhere to cultural aspects that are mostly adopted by society.

\section{CONCLUSION}

In the use of female members' use of financing funds, most of the respondents stated that they used them for additional business capital. However, a small proportion used the funds for consumptive needs. This shows that female members' level of willingness to be more independent in high because they do not want to only expect from their husbands. The existence of BMT in the Cianjur Regency has played a role in empowering the economy of women indirectly. This can be seen from the increasing independence of female members. Besides that, they are also more careful in managing finances and participating in household decision making. Although there is no particular BMT program that deals with women's economic empowerment, the vision, and mission of women's empowerment are included in it. As for BMT's efforts in empowering the women's economy, they are monitoring the progress of women financing participants regularly and organizing recitation regularly every week, which is used as a means of gathering BMT parties with their members. 


\section{Jurnal Ilmiah Ekonomi Islam, 7(02), 2021, 923}

\section{REFERENCES}

Amalia, E. (2009). Keadilan Distributif dalam Ekonomi Islam: Penguatan Peran LKM dan UKM di Indonesia. Raja Grafindo Persada.

Bungin, B. (2005). Metode Penelitian Kuantitatif. Prenata Media.

Basrowi., \& Suwandi. (2008). Mamahami Penelitian Kualitatif. Rineka Cipta.

Chowdhury, A. (2009). Microfinance as A Poverty Reduction Tool: A Critical Assessment. Department of Economic and Social Affairs (DESA) Working Paper No. 89, 1-12.

Durrani, M.K.K. (2011). Role of Microfinance in Reducing Poverty: A Look at Social and Economic Factors. International Journal of Business and Social Science, 2(21), 138-144.

Husaeni, U.A., \& Dewi, T.K. (2019). Pengaruh Pembiayaan Mikro Syariah Terhadap Tingkat Perkembangan Usaha Mikro Kecil Menengah (UMKM) pada Anggota BMT di Jawa Barat. BJRM Bongaya Journal for Research in Management, 2(1), 48-56.

Husaeni, U.A., \& Dew, T.K. (2019). The Dynamics of the Development Of Baitul Maal Wa Tamwil In Indonesia With The SWOT Analysis Approach. International Journal Of Scientific \& Technology Research, 8(8), 1678-1685.
Jayengsari, R.A., \& Husnaeni, U.A. (2020). Management of Financial Inclusion in Islamic Banking: Evidence from Indonesia. Agregat: Jurnal Ekonomi dan Bisnis, 4(1), 44-58.

Ridwan, M. (2011). Manajemen Baitul Maal wa Tamwil (BMT). UII Press.

Sen, A. (1981). Poverty and Famines: An Essay on Entitlement and Deprivation. Oxford University Press.

Shastri, R.K. (2009). Microfinance and Poverty Reduction in India: A Comparative Study with Asian Countries. African Journal of Business Management, 4, 136-140.

Sobana, D.H. \& Husaeni, U.A. (2019). Economic Empowerment of Poor Women with Grameen Bank Patterns on Baitul Mal Wa Tamwil Ibadurrahman. International Journal of Islamic Economics and Finance Studies (IJISEF), 5(1), 40-59.

Yunus, M., \& Jolis, A. (2010). Banker to the Poor: The Story of The Grameen Bank. Aurum Press Ltd. 